\title{
Organinių mulčių poveikis segetalinei florai ir augalų derlingumui
}

Jurgita Munikienè,

Aušra Sinkevičienė,

Darija Jodaugienè,

Vaida Steponavičienè

Aleksandro Stulginskio universitetas,

Studentu g. 11,

LT-53361 Akademija, Kauno r.

El.paštas: ausrasinkevicienelzuu@gmail.com
Tyrimo tikslas - ịvertinti ịvairių organinių mulčiu ịtaką pasèlių piktžolètumui (piktžolių dygimo dinamikai, piktžolių gausumui), valgomosios bulvès (Solanum tuberosum L.) ir raudonojo burokèlio (Beta vulgaris subsp. vulgaris convar. vulgaris var. vulgaris) derlingumui.

Lauko eksperimentas atliktas 2011-2012 m. Prienų rajone, Būčkiemio kaime. Dirvožemis - karbonatingas, giliau glèjiškas išplautžemis. Atlikus tyrimus nustatyta, kad visi tirti organiniai mulčiai daugeliu atvejų mažino piktžolių dygimą. Šiaudų, pjuvenų ir žolès mulčiai esmingai slopino (2,0-8,7 karto) piktžolių dygimą. Trumpaamžiu piktžolių dygimą esmingai stelbè visi organiniai mulčiai (2,1-9,7 karto). Tačiau skirtingai veikè trumpaamžių piktžolių rūšinę sudètị: visi organiniai mulčiai esmingai stabdè paprastosios rietmenès dygimą - 3,3-4,7 karto, dirvinès našlaitès - 3,4-6,5 karto, trikertès žvaginès - 1,2-2,3 karto (išskyrus žolès mulčią). Daugiamečiu piktžolių dygimą šiaudų, pjuvenų ir žolès mulčiai mažino 1,6-2,7 karto. Pjuvenų ir žolès mulčiai stabde paprastojo varpučio dygimą - 1,33,6 karto, dirvinio asiūklio - 2,7-5,0 karto (išskyrus šiaudų mulčią). Žolès mulčias turèjo tendenciją didinti (2011) burokèlių derlingumą $\left(65,29 \mathrm{Mg} \mathrm{ha}^{-1}\right)$, pjuvenomis ir šiaudais mulčiuotuose laukeliuose nustatytas esmingai mažesnis $(1,4-$ 1,6 karto) derlingumas, palyginti su nemulčiuota dirva. Didžiausias bulvių derlius (2012) buvo gautas žole mulčiuotuose laukeliuose $-48,27 \mathrm{Mg} \mathrm{ha}^{-1}$, t. y. 12,8 \%, o mažiausias - pjuvenomis mulčiuotuose laukeliuose (net 1,9 karto).

Raktažodžiai: organiniai mulčiai, piktžolès, burokèliai, bulvès

\section{IVADAS}

Mulčio teorija atsirado XIX amžiuje. Viskonsine buvo atlikti paprasti kapiliarinio vandens kilimo eksperimentai, kurie atskleidè, kad purus „mulčio“ sluoksnis viršutineje stulpelio dalyje stipriai sumažino drègmès išgaravimą (Heinonen, 1985).

Pasaulyje plintant tausojančiam ūkininkavimui mulčiavimas igyja vis didesnę reikšmę (Kassam, Brammer, 2012). Mulčiavimas teigiamai veikia ne tik augalų produktyvumą, mažina šiltnamio efektą sukeliančių dujų išsiskyrimą iš dirvožemio, bet ir padidina organinès anglies kaupimąsi dirvožemyje (Lal, 2008). Pasèlių piktžolètumas - svarbus veiks- nys, stabdantis ekologinès žemdirbystès plitimą (Bond et al., 2001). Populiarejjant ekologinei žemdirbystei vis daugiau domimasi alternatyviomis piktžolių kontrolès priemonèmis (Rasmussen et al., 1995; Economou et al., 2002). Mulčiavimas, kaip piktžolių kontrolès priemonè, yra naudojama visame pasaulyje (Dao, 1987; Gupta, 1991).

Dirvos paviršiaus mulčiavimas naudingas dèl daugelio priežasčių: mažina pasèlių piktžolètumą, papildo maisto medžiagų atsargas (Bilalis et al., 2002; Radics, Bognar, 2004; Petersen, Röver, 2005; Jodaugienè ir kt., 2006), šiuo metu vis plačiau taikomas kaip piktžolių kontrolès priemone. Tai ypač svarbu ekologinèje (organinejje) žemdirbystès sistemoje 
auginant kokybiškas ir saugias augalines maisto žaliavas (Neuweiler, Bertschinger et al., 2003). Mulčiai, kaip piktžolių kontrolès priemonè, veikia keliais būdais. Jie sudaro tiesioginị barjerą, trukdantị dygti piktžolèms, taip pat saulès šviesai pasiekti dirvos paviršių. Kadangi šviesa būtina kai kurių rūšių piktžolių sẻklų dygimui (Lazauskas, 1990; Špokienè, 2003), todèl labai svarbu kuo anksčiau padengti dirvą mulčiu. Jei pagrindinis pasèlio mulčiavimo tikslas - piktžolètumo mažinimas, geriausiai tam tinka polietileno plèvelès, dažnai naudojamos auginant daržoves. Šios plèvelès sudaro barjerą dirvos paviršiuje, jo neịveikia nei trumpaamžès, nei daugiametès piktžolès (Fisher, 1995). Organiniai mulčiai stabdo dirvožemio eroziją (Edwards et al., 2000), gerina dirvos struktūrą ir jos patvarumą (Mulumba, Lal, 2008), mažina dirvožemio tankį, šlyties pasipriešinimą, didina poringumą (Unger, Jones, 1998; Oliveira, Merwin, 2001; Mulumba, Lal, 2008). Mulčiavimas padeda mažinti drègmès išgaravimą iš dirvožemio, palaiko vienodesnę jos temperatūrą (Lal, 1974; Ji, Unger, 2001; Kar, Kumar, 2007), sudaro geras sąlygas dirvoje gyvenantiems mikroorganizmams (Gegužis, 1998). Vienas iš pagrindinių organinių mulčių naudojimo privalumų - organinių medžiagų kiekio didejimas dirvožemyje (Paustin et al., 1997; Saroa, Lal, 2003). Natūralūs organinès kilmès mulčiai ilgainiui suyra ir patys tampa dirvožemio dalimi. Lètas maisto medžiagų atpalaidavimas besiskaidant mulčiams geriau atitinka augalų maisto medžiagų poreiki (Cline, Silvernail, 2001; Cherr et al., 2006). Mulčiavimui naudojamos ir po derliaus nuemimo ị dirvą itterpiamos ịvairios organinès medžiagos suyra per skirtingą laikotarpi (Abiven, Recous, 2007; Fang et al., 2007; Pascault et al., 2010), todèl jų poveikis trunka ne vienerius metus. I dirvožemi itterptos visos organinès medžiagos spartina mikrobiologinių procesų intensyvumą ir didina $\mathrm{N}_{2} \mathrm{O}$ ir $\mathrm{CO}_{2}$ emisiją (Vither et al., 2004). Mulčiavimui naudojamos augalinès kilmès liekanos turi ittakos ne tik dirvožemio savybèms, bet ir vèliau auginamiems augalams. Dauguma tyrèjų nurodo, kad pasèlių mulčiavimas organiniais mulčiais didina žemės ūkio augalų derlių (Sharma, 2003; Kar, Kumar, 2007; Singh et al., 2007).

Tyrimo tikslas - i̇vertinti ìvairių organinių mulčiu įtaką piktžolių dygimo dinamikai, bulvių ir burokèlių derlingumui.

\section{METODAI IR SĄLYGOS}

Tyrimai atlikti 2011-2012 m. Prienų rajone, Būčkiemio kaime, Jurgitos Munikienès ūkyje. Atliktas vieno veiksnio lauko eksperimentas. Taikyti skirtingi organiniai mulčiai: nemulčiuota (NE), smulkinti žieminių kviečių šiaudai (ŠD), pjuvenos (PJ), smulkinta žolè (ŽO).

Pradinio eksperimento laukelio plotis - 4,90 m., ilgis $-3 \mathrm{~m}$, plotas $-14,7 \mathrm{~m}^{2}$. Apskaitinio laukelio plotis $-3,5 \mathrm{~m}$., ilgis $-2 \mathrm{~m}$, plotas $-7 \mathrm{~m}^{2}$. Variantai pakartojimuose išdèstyti rendomizuotai (atsitiktine tvarka). Eksperimentas vykdytas 3 pakartojimais. Šiaudų, pjuvenų ir žolès mulčias uždètas $7 \mathrm{~cm}$ storio sluoksniu.

Dirvožemis - karbonatingas, giliau glejjiškas išplautžemis (Calc(ar)i-Endohypogleyic Luvisol) (Buivydaitė ir kt., 2001). Granuliometrinè sudètis - drenuotas vidutinio sunkumo priemolis ant priesmèlio paklotu moreniniu moliu. Dirvožemio $\mathrm{pH}-6,3$, judriojo fosforo $-81,9 \mathrm{mg} \mathrm{kg}^{-1}$, judriojo kalio - 243,2 $\mathrm{mg} \mathrm{kg}^{-1}$, suminio azoto - 0,152 \%.

Augalai buvo auginami taikant ekologiniuose ūkiuose priimtinas auginimo technologijas. Pavasarị, dirvai pasiekus fizinę brandą, 2 kartus kultivuota. $2011 \mathrm{~m}$. visuose laukeliuose augintas raudonojo burokèlio pasèlis (Svetika ir kt., 1995). Veisle 'Pablo F1', sèklos norma - 320 tūkst. vnt. ha ${ }^{-1}$. Burokèliai sèti (gegužès $10 \mathrm{~d}$.) eilutèmis, atstumas tarp eilučiu - 0,7 m. Mulčias uždètas pasèjus raudonuosius burokèlius. Per vegetaciją nemulčiuoti laukeliai ravèti 3 kartus. Derlius nuimtas spalio $12 \mathrm{~d}$. Po derliaus nuèmimo likęs mulčias iterptas į dirvą rudeninio arimo metu.

$2012 \mathrm{~m}$. visuose laukeliuose augintas valgomosios bulvès pasèlis (Svetika ir kt., 1995). Veislè 'Beluga', sèklos norma - 55 tūkst. vnt. ha ${ }^{-1}$, arba 3,5 t/ha. Gegužès $10 \mathrm{~d}$. eilutèmis pasodintos bulvès, atstumas tarp eilučių - 0,7 m, vèliau vieną kartą akètos ir apkauptos. Mulčiuotos gegužès $25 \mathrm{~d}$. po bulvių apkaupimo. Per bulvių vegetaciją nemulčiuoti laukeliai ravėti 3 kartus. Derlius nuimtas rugsèjo $7 \mathrm{~d}$. Po derliaus nuemimo suarta.

Piktžolių dygimo dinamika. Piktžolių daigai kas 15 dienų skaičiuoti kiekviename laukelyje, keturiose pastoviose aikštelèse $(0,2 \times 0,3 \mathrm{~m})$. Kiekvienos apskaitos metu piktžolès išrautos, suskaičiuotos ir nustatyta jų rūšinè sudètis.

Žemès ūkio augalų derlingumas nustatytas sveriant. Nuėmus bulvių ir burokèlių derlių, 
šakniagumbiai ir šakniavaisiai pasverti. Itvertintas purvingumas, bulvių ir burokèlių šakniagumbiai ir šakniavaisiai plauti, džiovinti ir pasverti.

Tyrimų duomenys statistiškai ịvertinti dispersinès analizès metodu, kompiuterine programa SYSTAT 10 (SPSS Inc., 2000; Leonavičienè, 2007). Piktžolètumo duomenys, neatitinkantys normalaus skirstinio dèsnio, prieš statistinị ịvertinimą transformuoti naudojant funkciją $y=\lg 10(x+1)$.

Esant esminiam skirtumui tarp konkretaus varianto ir kontrolès (nemulčiuota), jo tikimybès lygmuo žymimas taip: ${ }^{*}$, kai $P \leq 0,050>0,010$ (skirtumai esmingi - $95 \%$ tikimybès lygis), ${ }^{* *}$, kai $P \leq 0,010>0,001$ (skirtumai esmingi - $99 \%$ tikimybès lygis); ${ }^{* * *}$, kai $P \leq 0,001$ (skirtumai esmingi - 99,99\% tikimybès lygis), $P>0,050$ - esminių skirtumu nèra (skirtumai esmingi - mažiau kaip $95 \%$ tikimybès lygis).

2011 m. gegužès mèn. vidutinè temperatūra buvo $12,7^{\circ} \mathrm{C}$. Šio mènesio temperatūra $0,1^{\circ} \mathrm{C}$ žemesnè už daugiametę. Kritulių iškrito $46,9 \mathrm{~mm}$. Birželio mèn. temperatūra buvo $18,1^{\circ} \mathrm{C}$, t. y. net $2,5^{\circ} \mathrm{C}$ aukštesnè negu daugiamete $\left(15,6^{\circ} \mathrm{C}\right)$. Kritulių iškrito birželio mẻn. $16 \mathrm{~mm}$ daugiau, palyginti su daugiamečiu vidurkiu. Birželio mèn. sąlygos buvo palankios intensyviai dygti piktžolèms. Liepos mèn. vidutinè temperatūra buvo šiltesne $2{ }^{\circ} \mathrm{C}$, palyginti su daugiamete. Mènesio vidutinè temperatūra siekè $19,6^{\circ} \mathrm{C}$. Aukščiausia temperatūra nustatyta trečią dekadą $\left(20,1{ }^{\circ} \mathrm{C}\right)$. Iškrito 144,0 mm kritulių, t. y. 61,0 mm daugiau nei daugiametis vidurkis. Meteorologinès sąlygos buvo labai palankios piktžolèms dygti. Rugpjūčio mèn. orai buvo šilti ir lietingi. Mènesio vidutinè temperatūra $-17,5^{\circ} \mathrm{C}$. Kritulių iškrito $152,0 \mathrm{~mm}$, 2,1 karto daugiau, palyginti su daugiamečiu vidurkiu. Rugsèjo mèn. orai buvo šilti, bet ne tokie lietingi, palyginti su rugpjūčiu. Mènesio vidutinè temperatūra $-13,6{ }^{\circ} \mathrm{C}$, t. y. $1,4{ }^{\circ} \mathrm{C}$ aukštesnè nei daugiametè. Kritulių iškrito 73,9 mm (ménesio kritulių suma 20,1 mm didesnè už daugiametę). Spalio mèn. buvo $\left(0,3{ }^{\circ} \mathrm{C}\right)$ šiltesnis ir sausesnis $(33,2 \mathrm{~mm})$, palyginti su daugiamečiu vidurkiu. Galima teigti, kad bulvems augti orai buvo labai palankūs.

2012 m. gegužès mèn. vidutinè temperatūra siekè $13,7^{\circ} \mathrm{C}$, t. y. $1,1{ }^{\circ} \mathrm{C}$ didesnè už daugiametę. Kritulių iškrito $50,3 \mathrm{~mm}$. Birželio mèn. temperatūra $-15,3{ }^{\circ} \mathrm{C}$, t. y. $0,3{ }^{\circ} \mathrm{C}$ aukštesnè nei daugiamete $\left(15,6^{\circ} \mathrm{C}\right)$. Kritulių birželio mèn. iškrito $26,7 \mathrm{~mm}$ daugiau, palyginti su daugiamečiu vidurkiu. Liepos mèn. vidutinè temperatūra buvo aukštesnè nei daugiametè $\left(1,8^{\circ} \mathrm{C}\right)$. Mènesio vidutinè temperatūra $-19,4^{\circ} \mathrm{C}$. Aukščiausia temperatūra nustatyta pirmą dekadą $\left(20,3{ }^{\circ} \mathrm{C}\right)$. Iškrito $112,8 \mathrm{~mm}$ kritulių, t. y. $21,8 \mathrm{~mm}$ daugiau nei daugiametis vidurkis. Meteorologinès sąlygos buvo labai palankios piktžolèms dygti. Rugpjūčio mèn. orai buvo šilti, tačiau kritulių iškrito mažai. Mènesio vidutinè temperatūra - $17,1{ }^{\circ} \mathrm{C}$. Kritulių - 69,2 mm, t. y. 1,1 karto mažiau, palyginti su daugiamečiu vidurkiu. Didžiausias kritulių kiekis iškrito pirmą dekadą - 49,6 mm, o antrą dekadą - tik 0,7 mm. Rugsèjo mèn. orai buvo šilti ir lietingi, palyginti su rugpjūčiu. Mènesio vidutinè temperatūra $-13,3^{\circ} \mathrm{C}$, t. y. $0,2{ }^{\circ} \mathrm{C}$ aukštesnè nei daugiametè. Kritulių iškrito 67,2 mm (mènesio kritulių suma 13,4 mm didesnè už daugiametę kritulių sumą).

$2011 \mathrm{~m}$. augalų vegetacijos periodo HTK - apie 2,0 . Tai drègmès perteklius, tačiau per vegetacijos periodą drègmè buvo pasiskirsčiusi netolygiai. Gegužès pabaigoje nustatytas optimalus vegetacijos periodas. Birželio mèn. pradžioje buvo sausa, o pabaigoje nustatyta optimali drègmè. Liepos mèn. pradžioje nustatytas drégmès perteklius, pabaigoje kritulių sumažèjo. Nuo rugpjūčio pradžios iki pabaigos buvo šlapia. Rugsèjo pradžioje drègmès sumažèjo iki nepakankamo drègnio, rugsèjo pabaigoje drègmès kiekis padidejo iki pertekliaus. Spalio pradžioje drègmès kiekis sumažèjo iki sauso. Didžiausias drègnumas (HTK 5,1) užfiksuotas rugpjūčio pabaigoje. Galima teigti, kad orai buvo šilti ir drègni, palankūs augalams augti.

$2012 \mathrm{~m}$. augalu vegetacijos periodo HTK - apie 1,7 . Tai rodo perteklinį drègnumą, tačiau per vegetacijos periodą drègmè buvo pasiskirsčiusi netolygiai. Nuo gegužès pradžios iki rugpjūčio pradžios nustatytas šlapias periodas. Rugpjūčio mèn. pabaigoje buvo sausa.

Rugsèjo pradžioje labai sumažèjo drègmès (HTK 0,5), tai mažiausias drégnumas per visą tiriamąji laikotarpi. Didžiausias drègnumas (HTK 2,9) užfiksuotas liepos pradžioje. Galima teigti, kad orai buvo šilti ir drègni, palankūs augalams augti.

\section{REZULTATAI}

Pasèlių piktžolètumas - svarbus veiksnys, stabdantis ekologinęžemdirbystę (Bond et al., 2001). Populiarèjant ekologinei žemdirbystei, vis daugiau domimasi 
alternatyviomis piktžolių kontrolès priemonèmis (Rasmussen etal., 1995; Economou et al., 2002). Mulčiavimas, kaip piktžolių kontrolès priemonè, naudojama visame pasaulyje (Dao, 1987; Gupta, 1991). Mokslininkai nustate, kad organiniai mulčiai esmingai mažina piktžolių dygimą (Sinkevičienè et al., 2009; Subhan ud Din et al., 2013b). Ant dirvos paviršiaus paskleisti organiniai mulčiai mažina šviesos patekimą i dirvą, kuri reikalinga piktžolėms dygti. Dèl šios priežasties stipriai mažeja piktžolių skaičius (Teasdale, Mohler, 2000). Dirvos paviršiuje esantis mulčias - fizinis barjeras, stabdantis piktžolių dygimą.

Nustačius 2011 m. išdygusių piktžolių kiekị per visą tyrimų laikotarpi paaiškejjo, kad piktžolių dygimą šiaudų, pjuvenų ir žolès mulčiai esmingai mažino 2,7-6,7 karto, palyginti su nemulčiuota dirva (1 pav.).

Analizuojant $2012 \mathrm{~m}$. gautus tyrimu duomenis matyti, kad daugiausia $\left(1335,8\right.$ vnt. $\left.\mathrm{m}^{-2}\right)$ piktžolių sudygo nemulčiuotoje dirvoje (1 pav.). Padengus dirvą mulčiais, piktžolių dygimas esmingai pasikeitè. Šiaudų mulčias piktžolių dygimą mažino 4,7 karto, pjuvenų - 8,7 karto, o žolès - 2,0 karto, palyginti su nemulčiuota dirva.

Apibendrinat dviejų tyrimų metų duomenis galima teigti, kad visi organiniai mulčiai esmingai mažino piktžolių dygimą.

Trumpaamžès piktžolès. Mokslinèje literatūroje nurodoma, kad mulčiavimas labiausiai mažina trumpaamžių piktžolių skaičių, ypač jų dygimą (Singh et al., 2001; Wiens et al., 2005).
Ant dirvos paviršiaus paskleisti organiniai mulčiai trukdo patekti ị dirvą šviesai, taip reikalingai piktžolių dygimui. Dèl šios priežasties stipriai mažeja piktžolių skaičius (Teasdale, Mohler, 2000). Tai svarbiausia mulčiuotų pasèlių piktžolètumo mažèjimo priežastis, dirvos paviršiuje esantis mulčias - fizinis barjeras, stabdantis piktžolių dygimą.

Gauti 2011 m. tyrimų duomenys rodo, kad trumpaamžių piktžolių dygimą šiaudų, pjuvenų ir žolès mulčiai esmingai mažino 2,9-6,9 karto, palyginti su nemulčiuota dirva (2 pav.).

Analizuojant sudygusių trumpaamžių piktžolių gausumą per visą augalų vegetaciją matyti, kad 2012 m. visi organiniai mulčiai esmingai slopino nuo 2,1 iki 9,7 karto trumpaamžių piktžolių dygimą, palyginti su nemulčiuotais laukeliais (2 pav.).

Dviejų tyrimų metų duomenys rodo, kad visi organiniai mulčiai esmingai stelbe piktžolių dygimą.

Paprastoji rietmenè (Echinochloa crus-galli (L.) P. Beauv.). Kaip nurodoma literatūroje, mulčiavimas labiausiai mažina trumpaamžių piktžolių skaičių (Singh et al., 2001). A. Sinkevičienè (2011) nustatè, kad naudojant įvairius organinius mulčius sumažèja paprastosios rietmenès gausumas nuo 2,4 iki 805 kartų.

$2011 \mathrm{~m}$. gauti tyrimu duomenys rodo, kad paprastosios rietmenès kiekis per visą tyrimų laikotarpi buvo didžiausias (5199,7 vnt. $\left.\mathrm{m}^{-2}\right)$ nemulčiuotoje dirvoje (3 pav.). Dirvos paviršių padengus organiniais mulčiais, matyti esmingas paprastosios rietmenès dygimo mažèjimas. Šiaudais mulčiuotoje dirvoje paprastosios rietmenès sudygo 915,2 vnt. $\mathrm{m}^{-2}$,

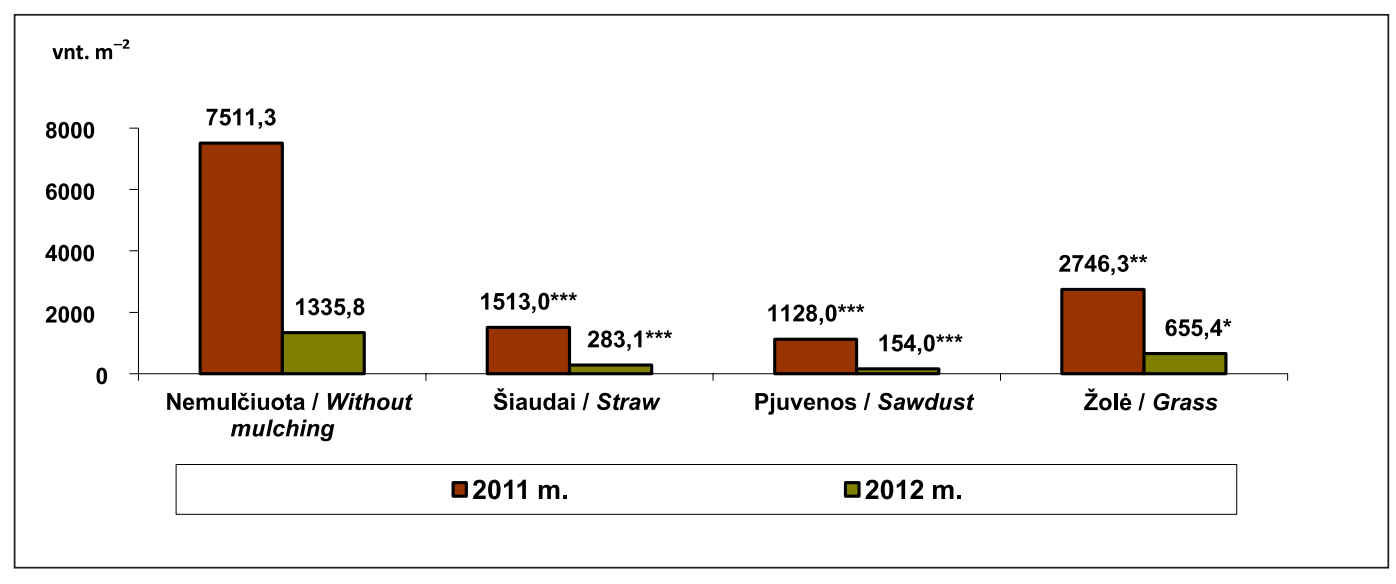

1 pav. Organinių mulčių ịtaka piktžolių gausumui per vegetaciją, vnt. m², 2011-2012 m.; skirtumai esmingi: ${ }^{*}$ - $95 \%$ tikimybès lygis, ${ }^{* *}$ - $99 \%$ tikimybès lygis, ${ }^{* *}-99,9 \%$ tikimybès lygis Fig. 1. The influence of different organic mulches on weed emergence, number $m^{-2}, 2011-2012$; ${ }^{*}-95 \%$ probability level, ${ }^{* *}-99 \%$ probability level, ${ }^{* *}-99.9 \%$ probability level 


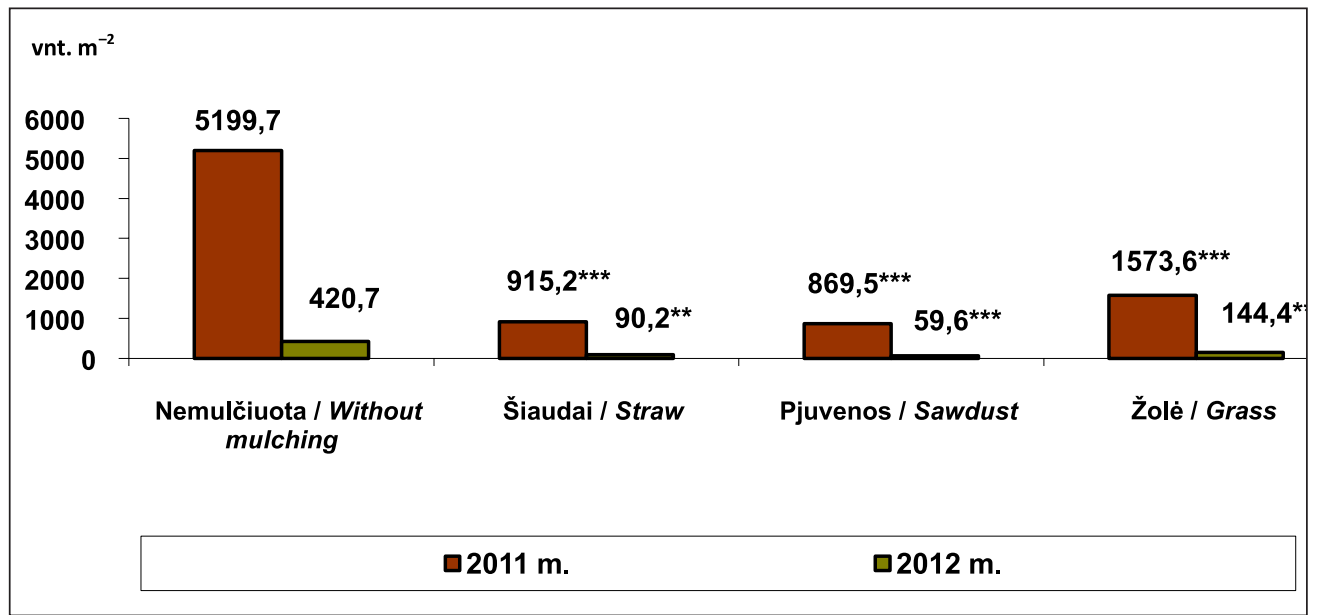

2 pav. Ivairių organinių mulčių ịtaka trumpaamžių piktžoliu gausumui, vnt. $\mathrm{m}^{-2}, 2011-$ 2012 m.; skirtumai esmingi: ${ }^{\star}$ - $95 \%$ tikimybès lygis, ${ }^{* *}$ - $99 \%$ tikimybès lygis, ${ }^{* *}$ - 99,9\% tikimybès lygis

Fig. 2. The influence of different organic mulches on weed emergence, number $\mathrm{m}^{-2}, 2011-$ 2012; ${ }^{*}-95 \%$ probability level, ${ }^{* *}-99 \%$ probability level, ${ }^{* * *}-99.9 \%$ probability level

t. y. 5,7 karto esmingai mažiau negu nemulčiuotoje. Pjuvenų mulčias paprastosios rietmenès dygimą esmingai mažino 6,0 karto, žolès - 3,3 karto, palyginti su nemulčiuotais laukeliais.

2012 m. paprastosios rietmenès sudygo žymiai mažiau nei praejjusiais metais. Visą tyrimų laikotarpi silpniausiai paprastosios rietmenès dygimą stabdè žolès mulčias, nors šios piktžolès sudygo esmingai (2,9 karto) mažiau. Ypač geru slopinamuoju poveikiu išsiskyrè šiaudų ir pjuvenų mulčiai. Jais padengtuose laukeliuose paprastosios rietmenès dygimas sumažejo 4,7-7,1 karto, palyginti su nemulčiuotais laukeliais.
Apibendrinat dviejų tyrimų metų duomenis galima teigti, kad visi organiniai mulčiai esmingai mažino paprastosios rietmenès dygimą.

Dirvinè našlaitė (Viola arvensis L.). $2011 \mathrm{~m}$. gauti tyrimų duomenys rodo, kad dirvinès našlaitès per visą tyrimų laikotarpi daugiausia buvo (494,6 vnt. $\mathrm{m}^{-2}$ ) nemulčiuotoje dirvoje (4 pav.).

Dirvos paviršių padengus organiniais mulčiais, matyti esmingas šios piktžolès dygimo mažejimas nuo 3,4 iki 10,8 karto, palyginti su nemulčiuotais. Žole mulčiuotoje dirvoje dirvinès našlaitès sudygo nuo 1,3 karto neesmingai mažiau, nei nemulčiuotuose laukeliuose.

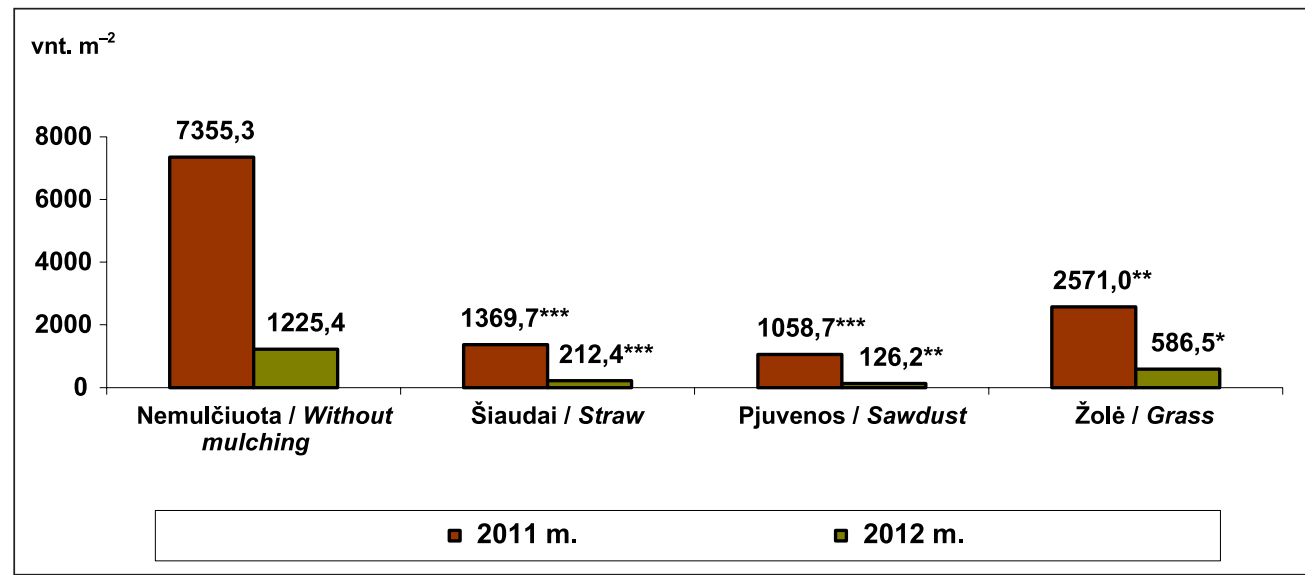

3 pav. Ivairių organinių mulčių ịtaka paprastosios rietmenès gausumui, vnt. $\mathrm{m}^{-2}, 2011-$ 2012 m.; skirtumai esmingi: ${ }^{\star *}$ - $99 \%$ tikimybès lygis, ${ }^{* *}$ - 99,9 \% tikimybès lygis

Fig. 3. The influence of different organic mulches on Echinochloa crus-galli (L.) P. Beauv. density, number $m^{-2}, 2011-2012{ }^{* *}-99 \%$ probability level, ${ }^{* * *}-99.9 \%$ probability level 


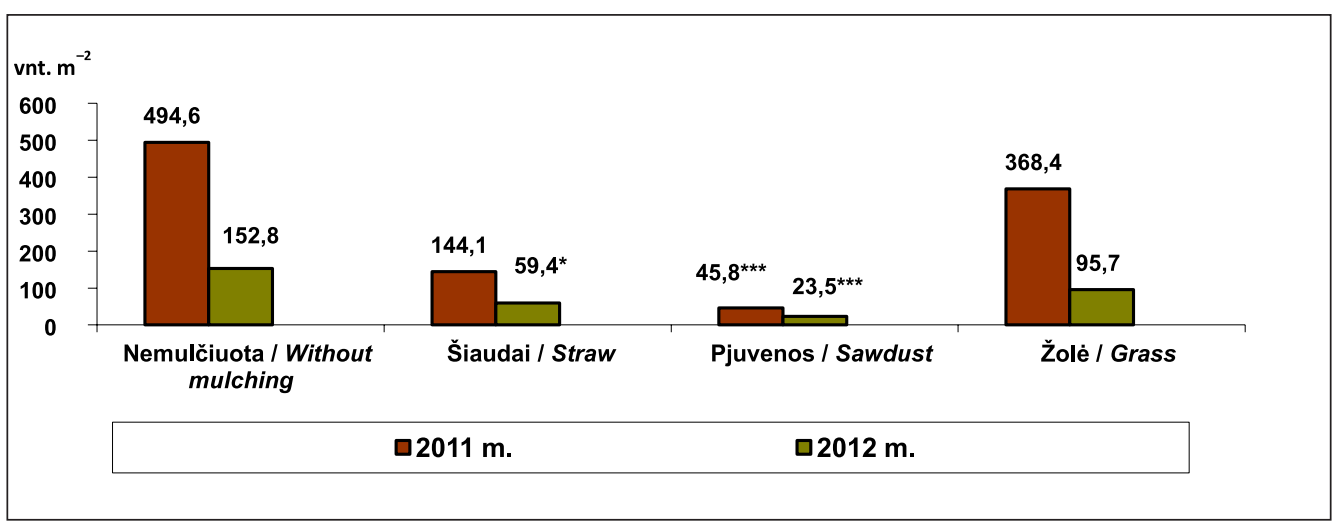

4 pav. Ivairių organinių mulčių įtaka dirvinès našlaitės gausumui, vnt. $\mathrm{m}^{-2}, 2011-2012$ m.; skirtumai esmingi: ${ }^{*}-95 \%$ tikimybès lygis, ${ }^{* *}-99,9 \%$ tikimybès lygis

Fig. 4. The influence of different organic mulches on Viola arvensis L. density, number $m^{-2}, 2011-$ 2012; ${ }^{*}-95 \%$ probability level, ${ }^{* * *}-99.9 \%$ probability level

2012 tyrimų metais dirvinès našlaitės sudygo žymiai mažiau, palyginti su praejjusiais (2011) metais. Visą tyrimų laikotarpi silpniausiai šios piktžolès dygimą stabdè žolès mulčias (1,6 karto), palyginti su nemulčiuota dirva. Ypač geru slopinamuoju poveikiu išsiskyrè šiaudų ir pjuvenų mulčiai, skirtumai esminiai - nuo 2,6 iki 6,5 karto, palyginti su nemulčiuotais laukeliais.

Apibendrinat dviejų tyrimų metų duomenis galima teigti, kad šiaudų ir pjuvenų mulčiai esmingai mažino dirvinès našlaitès dygimą.

Trikertė žvaginè (Capsella bursa-pastoris L.). $2011 \mathrm{~m}$. gauti tyrimų duomenys rodo, kad trikertès žvaginès kiekis per visą tyrimų laikotarpi buvo didžiausias $\left(335,0\right.$ vnt. $\left.\mathrm{m}^{-2}\right)$ nemulčiuotoje dirvoje (5 pav.).
Padengus dirvą šiaudų ir pjuvenų mulčiais, nustatytas esmingas trikertès žvaginès dygimo mažèjimas. Šiaudais mulčiuotoje dirvoje trikertès žvaginès sudygo 33,4 vnt. $\mathrm{m}^{-2}$, t. y. 10,0 kartų esmingai mažiau nei nemulčiuotoje. Pjuvenų mulčias šios piktžolès dygimą esmingai mažino net 60,0 kartų, o žolès mulčias trikertès žvaginès dygimą mažino neesmingai 7,3 karto, palyginti su nemulčiuota dirva.

2012 tyrimų metais trikertès žvaginès sudygo žymiai mažiau, palyginti su praejusiais (2011) metais. Visą tyrimų laikotarpi stipriausiai trikertès žvaginès dygimą stabdè pjuvenų mulčias - piktžolès sudygo esmingai 22,3 karto mažiau. Šiaudų ir žolès mulčiais padengtuose laukeliuose trikertès žvaginès dygimas sumažejo nuo 1,3-2,4 karto, palyginti su nemulčiuotais laukeliais.

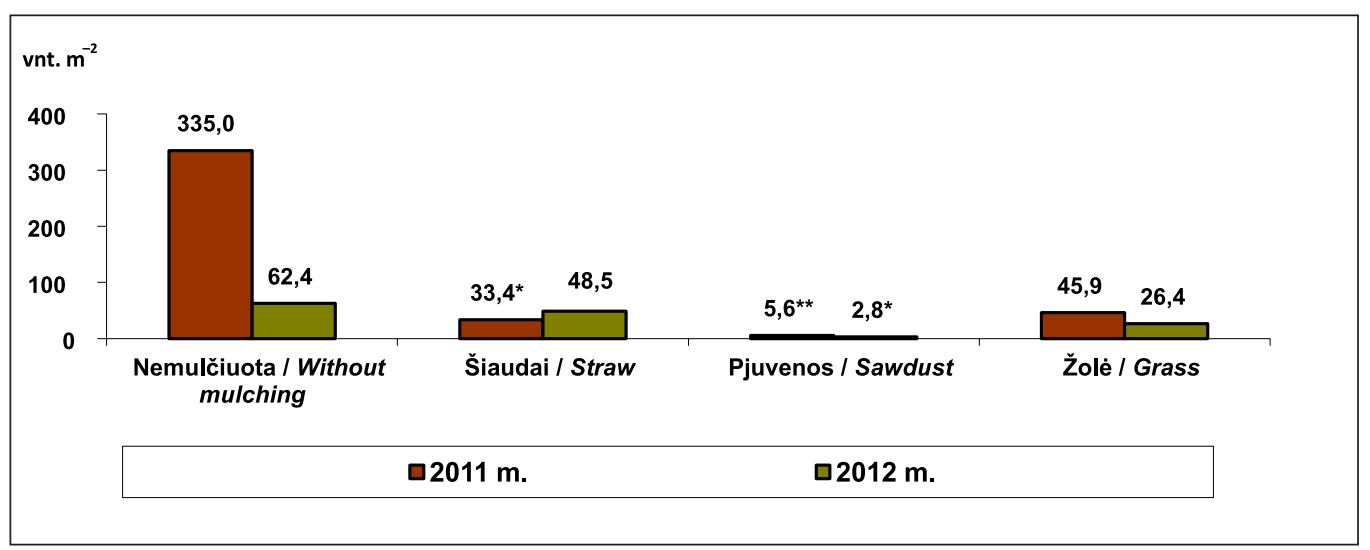

5 pav. Ivairių organinių mulčiu įtaka trikertės žvaginės gausumui, vnt. $\mathrm{m}^{-2}, 2011-2012 \mathrm{~m}$.; skirtumai esmingi: ${ }^{*}-95 \%$ tikimybès lygis

Fig. 5. The influence of different organic mulches on Capsella bursa-pastoris L. density, number $m^{-2}, 2011-2012 ;{ }^{*}-95 \%$ probability level 
Apibendrinat dviejų tyrimų metų duomenis galima teigti, kad visi organiniai mulčiai stabde trikertès žvaginès dygimą, tačiau geriausiu slopinamuoju poveikiu pasireiškè pjuvenų ir šiaudų mulčiai.

Daugiametės piktžolės. Analizuojant daugiamečių piktžolių gausumą per 2011 m. tyrimų laikotarpi nustatyta, kad skirtingi organiniai mulčiai neturejjo esminès įtakos jų atžèlimui (6 pav.). Šiaudų ir pjuvenų mulčiai turejjo tendenciją mažinti daugiamečių piktžolių atžèlimą, palyginti su nemulčiuotais laukeliais, o žolès mulčias daugiamečių piktžolių dygimą padidino 1,1 karto, palyginti su nemulčiuota dirva. Panašius tyrimus gavo ir kiti mokslininkai. Mulčiavimas smulkinta žole sudaro palankesnes sąlygas trumpaamžių ir daugiamečiu piktžolių dygimui antroje vasaros pusēje, nes didžioji dalis šio mulčio suyra (Jodaugienė ir kt., 2006).

2012 m. analizuojant daugiamečių piktžolių gausumą per visą tyrimų laikotarpí nustatyta, kad daugiausia (109,5 vnt. $\left.\mathrm{m}^{-2}\right)$ daugiamečių piktžolių atžèlè nemulčiuotoje dirvoje (6 pav.). A. Sinkevičienè (2011) teigia, kad padengus dirvos paviršiu organiniais mulčiais buvo nustatytas mažejantis daugiamečiu piktžolių atžèlimas. Mūsų gauti tyrimų duomenys irgi tai patvirtina. Šiaudų ir žolès mulčiai daugiamečių piktžolių atžèlimą mažino neesmingai - 1,6 karto, o pjuvenų esmingai - 4,0 kartais, palyginti su nemulčiuota dirva.

Paprastasis varputis (Elytrigia repens (L.) Nevski). Analizuojant paprastojo varpučio atžèlimą per visą $2011 \mathrm{~m}$. tyrimų laikotarpi matyti, kad esmingai daugiausia šios piktžolès šakniastiebių $\left(65,2\right.$ vnt. $\left.\mathrm{m}^{-2}\right)$ buvo šiaudais mulčiuotoje dirvoje, palyginti su nemulčiuotais laukeliais (7 pav.). Pjuvenų mulčias paprastojo varpučio atžèlimą didino 1,4 vnt. $\mathrm{m}^{-2}$, žolès - $\left(12,5\right.$ vnt. $\left.\mathrm{m}^{-2}\right)$, bet neesmingai, palyginti su nemulčiuota dirva.

2012 m. nustačius paprastojo varpučio atžèlimą, matyti, kad labiausiai esmingai šios piktžolès atžèlimą stabdè pjuvenų mulčias - 3,6 karto, palyginti su nemulčiuota dirva. Šiaudų mulčias paprastojo varpučio atžèlimą didino 1,0 kartą, žolès - 1,3 karto mažino, tačiau neesmingai.

Apibendrinat dviejų tyrimų metų duomenis galima teigti, kad šiaudų mulčias didino paprastojo varpučio atžèlimą, o geriausiu slopinamuoju poveikiu pasireiškè pjuvenų mulčias.

Dirvinis asiūklis (Eguisetum arvense L.). 2011 m. žolès mulčias mažiausiai stabde dirvinio asiūklio atžèlimą. Šiaudų mulčias dirvinio asiūklio atžèlimą mažino 1,7 karto, pjuvenų - 1,8 karto, bet neesmingai, palyginti su nemulčiuotais laukeliais.

$2012 \mathrm{~m}$. pjuvenų mulčias esmingai (5,0 kartus) stabde dirvinio asiūklio atžèlimą. Mulčiuojant šiaudų ir žolès mulčiais pastebèta dirvinio asiūklio (2,73,5 karto) atžèlimo mažèjimo tendencija.

Apibendrinat dviejų tyrimų metų duomenis galima teigti, kad visi organiniai mulčiai turèjo tendenciją mažinti dirvinio asiūklio atžèlimą, tačiau esmingumai nustatyti tik pjuvenomis mulčiuotuose laukeliuose.

Ivairių organinių mulčių itaka raudonųjų burokèlių (Beta vulgaris subsp. vulgaris convar. vulgaris var. vulgaris) derlingumui.

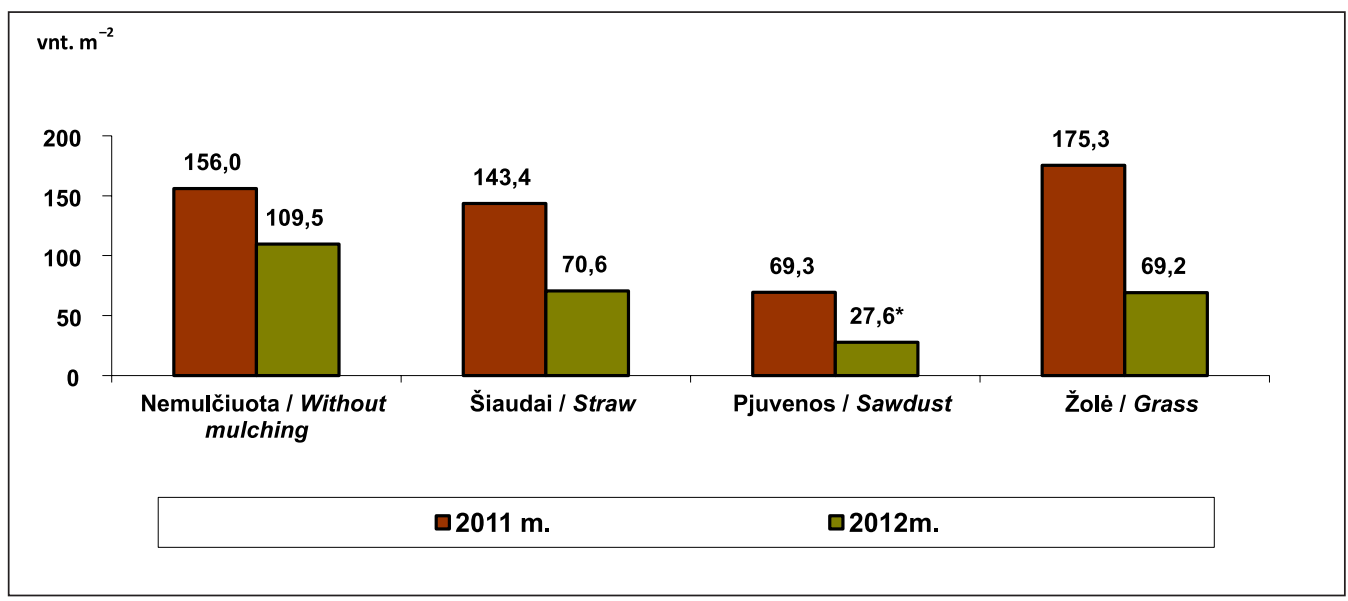

6 pav. Ivairių organinių mulčių itaka daugiamečių piktžolių gausumui, vnt. m² , 2011-2012 m.; skirtumai esmingi: ${ }^{\star}$ - $95 \%$ tikimybès lygis

Fig. 6. The influence of different organic mulches on perennial weed density, number $m^{-2}, 2011-$ 2012; ${ }^{\star}-95 \%$ probability level 


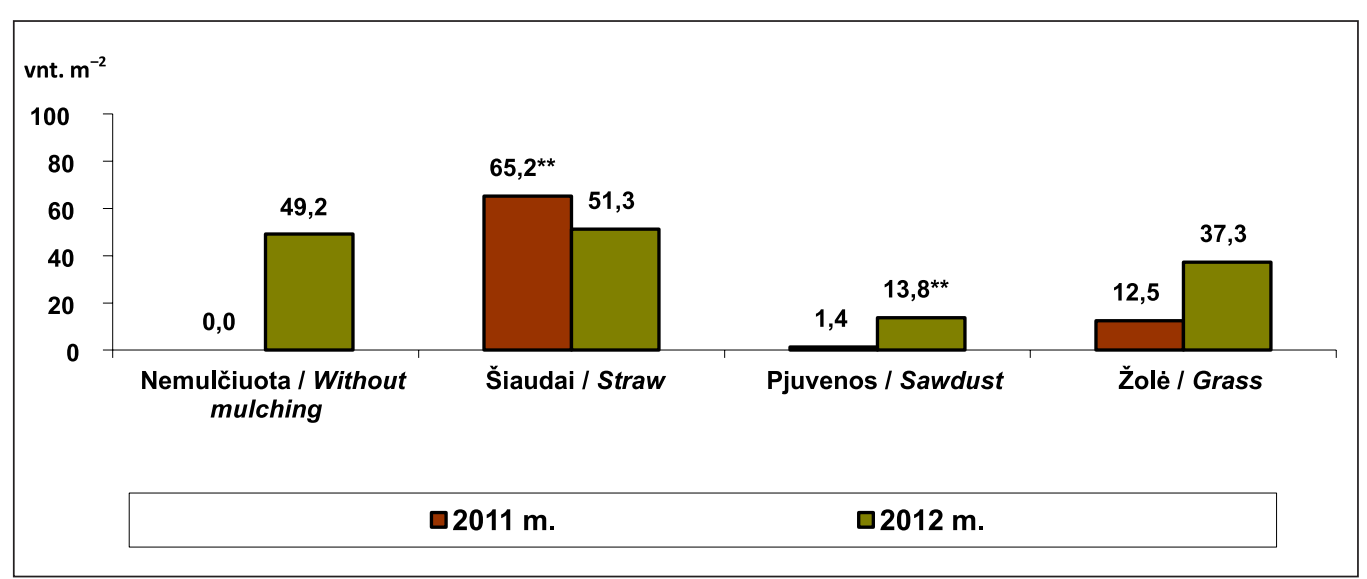

7 pav. İvairių organinių mulčių įtaka paprastojo varpučio gausumui, m ${ }^{-2}, 2011-2012$ m.; skirtumai esmingi: $* *-99 \%$ tikimybès lygis

Fig. 7. The influence of different organic mulches on Elytrigia repens (L.) Nevski density, number $m^{-2}, 2011-2012{ }^{* *}-99 \%$ probability level

2011 m. Prienų rajone, Būčkiemio kaime atliktame eksperimente didžiausias burokèlių derlingumas $\left(65,29 \mathrm{Mg} \mathrm{ha}^{-1}\right)$ gautas žole mulčiuotose laukeliuose (9 pav.). Tam galëjo turèti įtakos ne tik didesnis dirvos drègnumas, pastovesnè dirvos temperatūra, bet ir padideję suminio azoto ir judriojo kalio kiekiai dirvoje (žole mulčiuotuose laukeliuose). Burokèlių derlingumas kai kuriais mulčiais padengtuose laukeliuose buvo mažesnis, palyginti su burokèlių derlingumu nemulčiuotuose laukeliuose. Ypač šiuo požiūriu išsiskyrè pjuvenų mulčias. Pjuvenomis mulčiuotose laukeliuose burokèlių derlingumas buvo tik 37,95 $\mathrm{Mg} \mathrm{ha}^{-1}$, tai yra esmingai mažesnis net 1,6 karto, palyginti su burokèlių derlingumu nemulčiuotuose laukeliuo- se. Tyrimų rezultatai parodė, jog pjuvenų mulčias esmingai mažino piktžolių dygimą, tačiau jis esmingai mažino ir burokèlių derlingumą. Nors suminio azoto, judriojo kalio ir judriojo fosforo kiekiai dirvoje pjuvenomis mulčiuotuose laukeliuose nebuvo esmingai mažesni nei kituose laukeliuose. 2011 m. atliktais tyrimų duomenimis, esminių dirvos $\mathrm{pH}$ skirtumų ịvairiais mulčiais padengtuose laukeliuose nenustatyta. Galima daryti prielaidą apie alelopatinị mulčių poveikị augalams, kurie išskiria amino rūgščių darinius (Putnam, 1983).

Dirvos paviršiaus mulčiavimas šiaudais turèjo neigiamą ịtaką burokèlių derlingumui, palyginti su nemulčiuotais laukeliais, burokèlių derlingumas gautas 44,90 $\mathrm{Mg} \mathrm{ha}^{-1}$ arba esmingai 1,4 karto mažesnis.

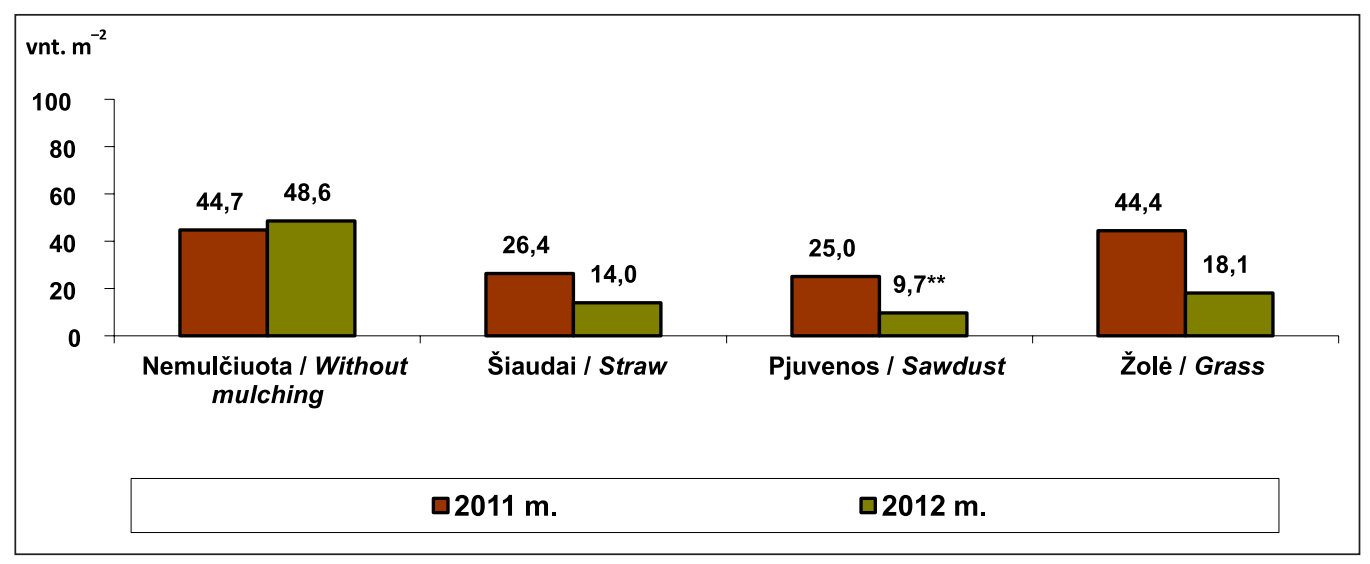

8 pav. Ivairių organinių mulčių ịtaka dirvinio asiūklio gausumui, m²-2 2011-2012 m. skirtumai esmingi: ${ }^{* *}-99 \%$ tikimybès lygis

Fig. 8. The influence of different organic mulches on Eguisetum arvense L. density, number $m^{-2}$, 2011-2012; ${ }^{* *}-99 \%$ probability level 


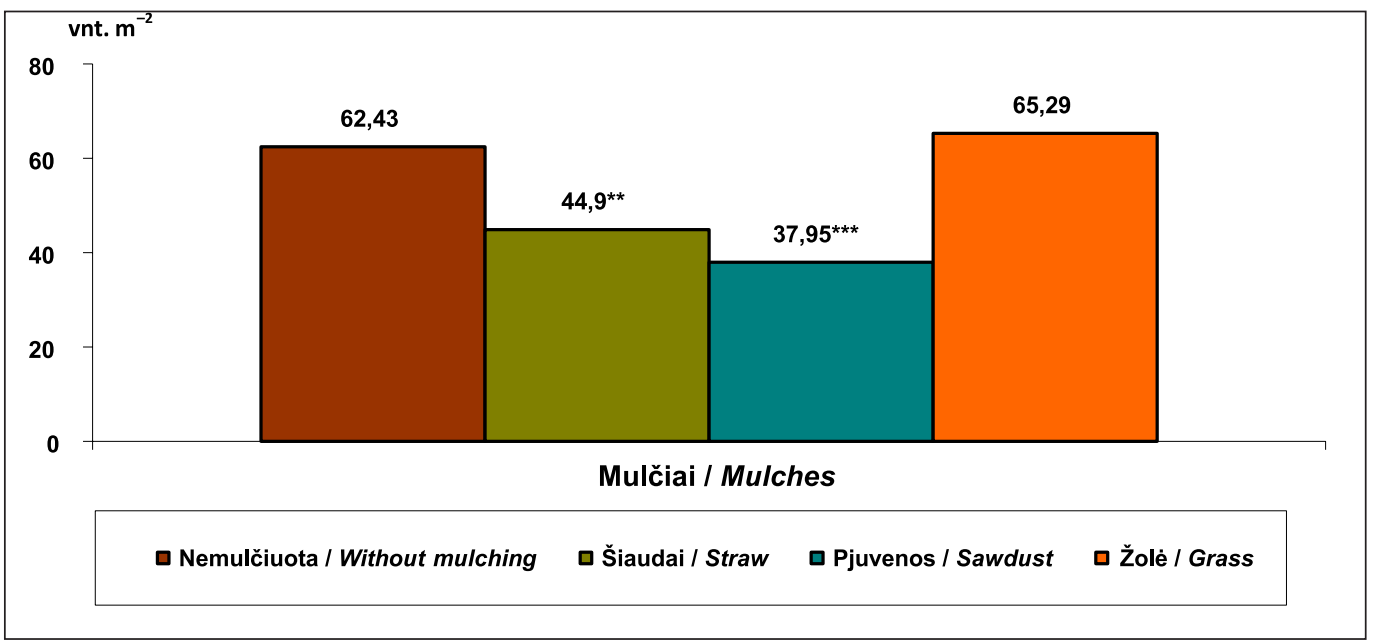

9 pav. Organinių mulčiu ịtaka raudonojo burokèlio derlingumui, $2011 \mathrm{~m}$. Skirtumai esmingi: ${ }^{* *}-99 \%$ tikimybès lygis, ${ }^{* *}-99,9 \%$ tikimybès lygis

Fig. 9. The influence of organic mulches on red beets productivity, 2011; **-99\% probability level, ***-99.9\% probability level

Ivairių organinių mulčių ittaka valgomosios bulvès (Solanum tuberosum L.) derlingumui. G. E. Brust (1994) nustatė, kad bulvių derlius mulčiuotuose laukeliuose būna 32-35\% didesnis nei nemulčiuotuose. Gausiausias derlius būna mulčiuojant ankstyvuosius augalus (Gill et al., 1996).

$2012 \mathrm{~m}$. atliktame eksperimente didžiausias bulvių derlingumas - 48,27 $\mathrm{Mg} \mathrm{ha}^{-1}$ gautas žole mulčiuotose laukeliuose (9 pav.). Ittakos galèjo turèti padidèję suminio azoto, judriojo kalio ir judriojo fosforo kiekiai dirvoje žole mulčiuotuose laukeliuose. Pjuvenomis mulčiuotuose laukeliuose bulvių derlingumas buvo tik 22,40 $\mathrm{Mg} \mathrm{ha}^{-1}$, tai yra esmingai mažesnis net 1,9 karto, palyginti su bulvių derlingumu nemulčiuotuose laukeliuose. Suminio azoto ir judriojo kalio kiekiai dirvožemyje pjuvenomis mulčiuotuose laukeliuose nebuvo esmingai mažesni, palyginti su kitais laukeliais.

$2012 \mathrm{~m}$. atliktais tyrimų duomenimis, esminių dirvos pH skirtumų ịvairiais mulčiais padengtuose laukeliuose nenustatyta. Galima daryti prielaidą apie alelopatini mulčių poveikị augalams. Augalų išskyros atsiranda po derliaus nuèmimo dirvos paviršiuje paskleidus ar itterpus augalines liekanas (veikiant lietui ir mikroorganizmams jos pradeda irti).

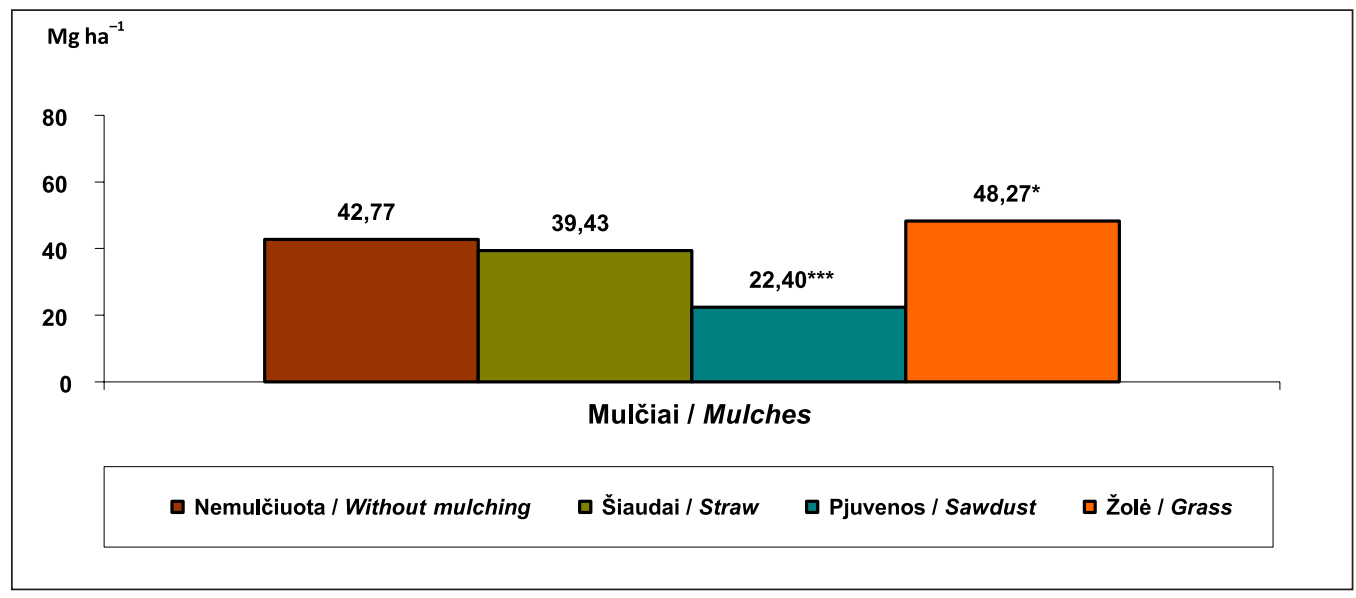

10 pav. Organinių mulčių ịtaka valgomosios bulvès derlingumui, 2012 m. Skirtumai esmingi: * $-95 \%$ tikimybès lygis, ${ }^{* * *}$ - 99,9\% tikimybès lygis

Fig. 10. The influence of organic mulches on potato productivity, 2012; *-95\% probability level, ***-99.9\% probability level 
Fiziologiškai aktyvias medžiagas i⿱ aplinką išskiria tiek žoliniai (dažniausiai piktžolès, net $30 \%$ augalų rūšių), tiek sumedèję gyvi augalai: šaknys, stiebai, lapai, žiedai, sèklos. Išskyros nuplaunamos lietaus, rasos lašų, kurios gali patekti ant greta augančiu augalų ir pasklisti ore, dirvoje (Lazauskas, 1990). Taip pat alelopatinèmis savybėmis pasižymi ir pūvantys šiaudai, kurie gali išskirti alifatines rūgštis, mikroorganizmai išskiria amino rūgščių darinius (Putnam, 1983).

Dirvos paviršiaus mulčiavimas šiaudais turejo neigiamą įtaką bulvių derlingumui, palyginti su nemulčiuotais laukeliais, jis gautas $39,43 \mathrm{Mg} \mathrm{ha}^{-1}$ arba 7,8 \% mažesnis.

\section{IŠVADOS}

1. Visi organiniai mulčiai esmingai mažino (nuo 2,0 iki 8,7 karto) piktžolių dygimą.

2. Skirtingi organiniai mulčiai esmingai slopino (nuo 2,1 iki 9,7 karto) trumpaamžių piktžolių dygimą, palyginti su nemulčiuotais laukeliais.

3. Organiniai mulčiai skirtingai veikè daugiamečių piktžolių atžèlimą: šiaudų ir pjuvenų mulčiai esminès įtakos neturejo, o žolès mulčias daugiamečių piktžolių atžèlimą mažino neesmingai tik antraisiais tyrimų metais.

4. İvairūs organiniai mulčiai skirtingai veikè bulvių ir burokèlių derlingumą. Esmingai didesnis $12,8 \%$ bulvių derlius gautas žole mulčiuotuose laukeliuose, o pjuvenų mulčias esmingai mažino 1,9 karto, palyginti su nemulčiuota dirva. Žolès mulčias turèjo tendenciją didinti burokèlių derlingumą $\left(65,29 \mathrm{Mg} \mathrm{ha}^{-1}\right)$, pjuvenomis ir šiaudais mulčiuotuose laukeliuose nustatytas esmingai mažesnis 1,4-1,6 karto derlingumas, palyginti su nemulčiuota dirva.

Gauta 20140625 Priimta 20141210

\section{LITERATŪRA}

1. Abiven S., Recous S. 2007. Mineralization of crop residues on the soil surface or incorporated in the soil under controlled conditions. Biology and Fertility of Soils. Vol. 43. P. 849-852.

2. Bilalis D., Sidiras N., Economou G., Vakali C. 2002. Effect of different levels of wheat straw soil surface coverage on weed flora in Vicia faba crops. Journal of Agronomy and Crop Science. Vol. 189. P. 233-241.
3. Bond W., Grundy A. C. 2001. Non-chemical weed management in organic farming systems. Weed Research. Vol. 41. No. 5. P. 383-405.

4. Brust G. E. 1994. Natural enemies in straw-mulch reduce Colorado potato beetle populations and damage in potato. Biological Control. Vol. 4. Issue 2. P. 163-169.

5. Cherr C. M., Scholberg J. M. S., Mcsorley R. 2006. Green manure approaches to crop production: a synthesis. Agronomy Journal. Vol. 98. P. 302-319.

6. Cline G. R., Silveranail A. F. 2001. Residual nitrogen and kill date effects on winter cover crop growth and nitrogen content in a vegetable production system. HortTechnology. Vol. 11. P. 219-225.

7. Dao T. H. 1987. Crop residues and management of annual grass weeds in continuous no-till wheat (Triticum aestivum). Weed Science. Vol. 33. P. 110114.

8. Economouc G. O., Tzakou A., Gani A. 2002. Allelopathic effect of Conyza albida on Avena sativa and Spirodela polyrhiza. Journal of Agronomy and Crop Science. Vol. 188. P. 248-253.

9. Fang S., Xie B., Zhang H. 2007. Nitrogen dynamics and mineralization in degraded agricultural soil mulched with fresh grass. Plant and Soil. Vol. 300. P. 269-280.

10. Fisher P. D. 1995. An alternative palstic mulching system for improved water management in dryland maize production. Agricultural Water Management. Vol. 27. Issue 2. P. 155-166.

11. Gegužis S. 1998. Daržovés šeimos stalui. Kaunas: Ükininko patarèjas.

12. Gill K. S., Gajri P. R., Chaudhary M. R., Singh B. 1996. Tillage, mulch and irrigation effects on corn (Zea mays L.) in relation to evaporative demand. Soil and Tillage Research. Vol. 39. Issues 3-4. P. 213-227.

13. Gutap G. N. 1991. Effects of mulching and fertilizer application on initial development of some tree species. Forest Ecology and Management. Vol. 44. P. 211-221.

14. Heinonen R. 1985. Soil Management and Crop Water Supply. 42 p.

15. Jodaugienè D., Pupalienè R., Urbonienè M., Pranckietis V., Pranckietienè I. 2006: The impact of different types of organic mulches on weed emergence. Agronomy Research. Vol. 4. P. 197-201.

16. Jodaugiené D., Pupaliené R., Urbonienė M. 2006. Itvarių organinių mulčių ịtaka trumpaamžių ir daugiamečių piktžolių dygimui. Mokslo darbai. Nr. 71(24).

17. Kar G., Kumar A. 2007. Effects of irrigation and straw mulch on water use and tuber yield of potato in eastern India. Agricultural Water Management. Vol. 94(109). P. 116.

18. Kassam A., Brammer H. 2012. Combining sustainable agricultural production with economic 
and environmental benefits. The Geographical Journal. Vol. 179. P. 11-18.

19. Lal R. 1974. Soil temperature, soil moisture and maize yield from mulched and unmulched tropical soils. Plant \& Soil. Vol. 40(1). P. 129-143.

20. Lal R. 2008. Crop residues as soil amendments and feedstock for bioethanol production. Waste Management. Vol. 28. P. 747-758.

21. Lazauskas P. 1990. Agrotechnika prieš piktžoles. Kaunas. 200 p.

22. Leonavičienė T. 2007. SPSS programu paketo taikymas statistiniuose tyrimuose. Vilnius: Vilniaus pedagoginio universiteto leidykla.

23. Mulumba L. N., Lal R. 2008. Mulching effects on selected soil physical properties. Soil and Tillage Research. Vol. 98. P. 106-111.

24. Neuweiler R., Berschinger L., Stamp P., Feil B. 2003. The impact of ground cover management on soil nitrogen levels, parameters of vegetative crop development, yield and fruit quality of strawberries. European Journal of Horticulture Science. Vol. 68. P. 183-191.

25. Oliveira M. T., Merwin I. A. 2001. Soil physical conditions in a New York orchard after eight years under different groundcover management systems. Plant Soil. Vol. 234. P. 233-237.

26. Pascault N., Nicolardot B., Bastian F., Thiébeau P., Ranjard L., Maron P-A. 2010. In situ dynamics and spatial heterogeneity of soil bacterial communities under different crop residue management. Environmental Microbiology. Vol. 60. P. 291-303.

27. Paustin K., Collins H. P., Paul E. A. 1997. Management controls of soil carbon. In: SOM in Temperate Agroecosystems: Long Term Experiments in North America. P. 15-49.

28. Petersen J., Röver A. 2005. Comparison of sugar beet cropping systems with dead and living mulch using a glyphosate-resistant hybrid. Journal of Agronomy and Crop Science. Vol. 191. P. 1-80.

29. Putnam A. R., Defrank J., Barnes J. P. 1983. Exploitation of allelopathy for weed control in annual and perennial cropping systems. Journal of Chemistry and Ecology. Vol. 9. P. 1001-1010.

30. Radics L., Bognar E. S. 2004. Comparison of different methods of weed control in organic green bean and tomato. Acta Horticulturae. No. 638. P. 189-196.

31. Rasmussen J., Ascard J. W. 1995. Weed control in organic farming systems. In: Ecology and Integrated Farming Systems. London: Wiley Publishers (UK). P. 49-67.
32. Saroa G. S., Lal R. 2003. Soil restorative efects of mulching on aggregation and carbon sequestration in Miamian soil in Central Ohio. Land Degradation Development. Vol. 14. P. 481-493.

33. Sharma R. R., Sharma V. P. 2003. Mulch influences fruit growth, albinism and fruit quality in strawberry (Fragaria $\times$ ananassa Duch.). Fruits. Vol. 58 . P. 221-227.

34. Singh K., Shukla G., Rawat C., Kumar S., Hazra C. 2001. Stability indices for weed management systems in forage oat (Avena sativa L.). Journal of Agronomy and Crop Science. P. 187, 217-222.

35. Singh R. S., Sharma R. R., Goyal R. K. 2007. Interacting effects of planting time and mulching on "Chandeler" strawberry (Fragaria $\times$ ananassa Duch.). Scientia Horticulturae. Vol. 111. P. 344-351.

36. Sinkevičienè A., Jodaugienè D., Pupalienè R., Urbonienè M. 2009. The influence of organic mulches on soil properties and crop yield. Agronomy Research. Vol. 7(1). P. 485-491.

37. Sinkevičienè A. 2011. Organiniu mulčiu poveikis dirvožemio savybèms, segetinei florai ir augalu derlingumui. Daktaro disertacija. Kaunas. 100 p.

38. SPSS 2000. InStat 10. Statistics I. USA. P. 663.

39. Subhan ud D., Ramzan M., Khan R., Rahman M., Haroon M., Khan T. A., Samad A. 2013b. Impact of tillage and mulching practices on weed biomass and yield components of maize under rainfed condition. Pakistan Journal of Weed Science Research. Vol. 19(2). P. 201-208.

40. Svetika P., Palaima K. 1995. Daržininkystè. Vilnius: Academia. $352 \mathrm{p}$.

41. Špokienè N. 2003. Piktžolès. Kaunas. 200 p.

42. Teasdale J. R., Mohler CH. L. 2000. The quantitative relationship between weed emergence and the physical properties of mulches. Weed Science. Vol. 48. P. 385-392.

43. Unger P. W., Jones O. R. 1998. Long-term tillage and cropping systems affect bulk density and penetration resistance of soil cropped to dryland wheat and grain sorghum. Soil and Tillage Research. Vol. 45(1-2). P. 39-57.

44. Vinther F. P., Hansen E. M., Olesen J. E. 2004. Effects of plant residues on crop perfomance, $\mathrm{N}$ mineralisation and microbial activity including field $\mathrm{CO}_{2}$ and $\mathrm{N}_{2} \mathrm{O}$ fluxes in unfertilised crop rotations. Nutrient Cycling in Agroecosystems. Vol. 70(2). P. 189-199.

45. Wiens M. J., Entz M. H., Martin R. C., Hammermeister A. M. 2005. Agronomic benefits of alfalfa mulch applied to organically managed spring wheat. Canadian Journal of Plant Science. Vol. 86. P. 121-131. 
Jurgita Munikienė, Aušra Sinkevičienè, Darija Jodaugienė, Vaida Steponavičienè

\section{THE EFFECT OF DIFFERENT ORGANIC MULCHES ON SEGETAL FLORA AND PLANT PRODUCTIVITY}

\section{Sum $m$ ary}

The research was carried out in 2011-2012. The experiments were done at the Būčkiemis Village, Prienai District. The soil type was Calc(ar)i-Endohypogleyic Luvisol.

All organic mulches decreased weeds germination. Wheat straw, sawdust and grass mulches significantly decreased the number of weed shoots by 2.0-8.7 times. Different types of organic mulches significantly decreased annual weed shoots (2.1-9.7 times). But there was different effect on the species composition of annual weeds: all organic mulches significantly decreased the germination of Echinochloa crus-galli - by 3.3-4.7 times, of Viola arvensis - by 3.4-6.5 times, of Capsella bursa-pastoris - by 1.2-2.3 times (except grass mulch).
All organic mulches decreased the emergence of perennial weeds by 1.6-2.7 times. Sawdust and grass mulches decreased the germination of Elytrigia repens - 1.3-3.6 times, of Eguisetum arvense - 2.7-5.0 times (except wheat straw mulch). A trend of edible beetroot crop (2011) productivity increase was determined for the plots applied with grass mulches (65.29 $\left.\mathrm{Mg} \mathrm{ha}^{-1}\right)$. The wheat straw and sawdust mulches significantly reduced edible beetroot crops productivity by $1.4-$ 1.6 times compared with the not mulched plots. The highest potato yield (2012) was established in plots mulched with grass - $48.27 \mathrm{Mg} \mathrm{ha}^{-1}$ higher, which is $12.8 \%$, and the lowest yield was in plots mulched with sawdust (even 1.9 times).

The aim of the work was to estimate the influence of different organic mulches on soil, weediness (dynamics of weed shooting, abundance of weeds), beetroot and potato productivity.

Key words: organic mulch, weeds, edible beetroot crops (Beta vulgaris subsp. vulgaris convar. vulgaris var. vulgaris), edible potato (Solanum tuberosum L.) 